\title{
An Experiment in Acquisitions with the Lamont Library List
}

Miss Simpson is chief, book acquisitions section, Air University Library.

$\mathrm{T}$

He Air University, engaged in the professional education of ranking United States Air Force officers, conducts an instructional program which stresses air power and the relationship of air power to world affairs. It is the mission of the library to support the courses of instruction as well as the research program. While the collection is particularly strong in aeronautics and the military, political and social sciences, all branches of knowledge are represented generally. The resources necessarily differ from those of a standard college library augmenting a normal undergraduate four year program.

In the spring of 1952 the Air University Library undertook the review of its book collection on an undergraduate level. The bibliography prepared by Charles B. Shaw, A List of Books for College Libraries (I93I), and the supplement, including publications of I93 I through 1938, were out of date for practical checking purposes. Since the Lamont Library at Harvard University is considered exemplary for undergraduate use, decision was made to examine its basic selections for possible adaptation. Harvard University generously loaned for review an author list of the original selections in card form. The list comprised about 36,000 titles assembled for the Lamont Library prior to the opening in January 1949. A classified subject catalog of the Lamont Library was published in the fall of 1953 and became available to all academic institutions as an important bibliographic aid.

Upon initiation of the survey, the holdings of the Air University Library already numbered I 50,000 books and serial publications as well as 500,000 security classified documents. The project was completed in the summer of 1953 with 15,650 of the entries on the selection list having been located in the card catalogs and order records. A total of 4,787 titles were selected for purchase, 2,594 of which were identical to those examined. Treatments, editions and recent publications more suitable for military use accounted for 2, 193 substitutes. Approximately 9,000 out-ofprint entries and about 3,000 in foreign languages were rejected for procurement. The remaining titles, although in print and available, were inapplicable to the needs of the Air University and accordingly were not acquired. The number of books purchased is shown by general Dewey subject classification, tabulated below.

In compiling titles for the Lamont $\mathrm{Li}$ brary, the basis for selection was the potential use of a book by Harvard undergraduates rather than the arrangement of a model collection. ${ }^{1}$ The same principle was embraced in the evaluation and integration for Air University requirements. Consideration of the use of a book by air force offi-

1 Williams, Edwin E., "The Selection of Books for Lamont," IIarvard Library Bullctin, III, r949, p. $39 \mathrm{I}$. 


\begin{tabular}{|c|c|c|}
\hline Class & $\begin{array}{c}\text { Identical } \\
\text { Titles }\end{array}$ & $\begin{array}{c}\text { Substitute } \\
\text { Titles }\end{array}$ \\
\hline OOO & 27 & 28 \\
\hline 100 & I 84 & 99 \\
\hline 200 & 63 & 36 \\
\hline 300 & 245 & 84 \\
\hline 400 & $4 \mathrm{I}$ & 96 \\
\hline 500 & 270 & I 75 \\
\hline 600 & 202 & 279 \\
\hline 700 & 224 & 528 \\
\hline $\int 800$ & $\int 516$ & $\int 210$ \\
\hline Fiction & 474 & 375 \\
\hline$\} 900$ & I 45 & $\int I 3 I$ \\
\hline Biography & 203 & I 52 \\
\hline Total & 2594 & 2193 \\
\hline
\end{tabular}

cers became a study in contrast between the requisites of a purely academic collection and those of a specialized military library.

It was not the intent to imitate the Lamont Library holdings but to employ the list of basic titles from a selective viewpoint. Three paramount factors colored its use as a buying guide. First, no undergraduate courses in the literal sense are offered at Air University. The educational program is directed toward the preparation of top-level air force officers for major positions of leadership. Varied subject fields are tapped for this specialized training, yet courses differ from those slanted especially toward the undergraduate. For instance, instruction in psychology, history, social, political, pure and applied science is not offered formally. These subjects, nevertheless, may be pertinent to air force education and research in their related aspects, such as mental measurements, personality, leadership, public opinion, world economy, current history, military science, aeronautics, management, international relations, geography, geopolitics, ethnology, military law and aviation medicine.

The second factor recognized that aca-

OCTOBER, 1954 
entries on large folio sheets. The entries on the photostatic copy were checked against the card catalogs for elimination of duplicates. Cards were typed for the remaining titles which were searched in Books in Print and Reference Catalogue of Current Literature and separated into in print and out-of-print categories. Both types were divided into the ten Dewey subject classes and then into minute decimal subdivisions before serious analysis could be attempted.

Each subject classification was reviewed on a parallel basis with the shelf list. In this manner it was possible to determine the augmentation each subject demanded, consistent with the needs of the Air University. The pure and applied sciences, fine arts and literature revealed a need for expansion, yet educational requirements precluded their full development on the undergraduate level. Laboratory courses, for example, not necessary to the curriculum and selection of titles in the sciences had to be approached from the descriptive and useful standpoint rather than the analytical.

A similar approach was employed in the development of the fine arts and literature collections. Since instruction is not given in these areas, titles were selected for the purpose of supporting general and cultural reading interests of student officers. Until the acquisitions policy was implemented in 1952, there was little provision either for fine arts or literature. This policy has been defined to provide books for leisure reading in all subject areas. The extensive individual interest demonstrated in fine arts resulted in the addition of 752 titles. The literature collection, long deficient, acquired I,575 titles of which 849 were fiction. Titles in literary history and criticism were kept to a minimum in favor of worthy works of all literatures.

Most of the foreign language books on the Lamont list represented literary classics and literary history and criticism. In selections for the Air University Library, consideration was given to the fact that linguistic proficiency is not a major requirement for specialized military education. The inferior quality of foreign editions was also a deciding point. As a result of these facts, all foreign literary works procured had to be obtained in English translation rather than in the language of origin.

There were few titles to be added in bibliography, religion and language. Bibliography had received concentrated attention earlier and extensive acquisitions had been made with emphasis upon intensifying the collection of bibliographic tools. Re ligion required only basic treatments, anthologies of representative writings and general coverage of world religions. In language the holdings were adequate in semantics as well as in books relating to the use of English. Since foreign languages are not taught at Air University, selections consisted largely of bilingual dictionaries, the spoken language and conversation and phrase books. Recordings of spoken language courses supplement the resources and are used advantageously by student officers slated for foreign duty.

Psychology, social science and history had comprehensive coverage in the library and the proportion of titles ordered in these classes was relatively small. As in the field of religion, the general materials in philosophy, such as basic texts, collections and encyclopedic works were sufficient to afford presentation of all philosophies. Biography, on the other hand, displayed a need for development in variety and scope. Accounts of well known figures of literary and artistic achievement were lacking. As the art of war is primarily a male enterprise, biographies of notable women, except for those prominent in the field of politi- 
cal history, were conspicuously absent.

Although only 4,787 books were selected to enhance subject areas in the Air University Library collection, the ratio was good considering the number of volumes already on hand and the variance in instructional approach. In this procurement it was necessary to achieve a balance within the subject fields coordinate with the shelf list. General representation being sufficient in many categories, especially literature, it was practical to obtain whenever possible anthologies and one volume editions of selected or collected writings rather than individual volumes of separate titles. Whereas variations in editions and translations are useful in an undergraduate library, for local purposes one standard edition of the writings selected for purchase was usually satisfactory. In the case of revisions effecting changes in content, the latest edition, of course, was essential.

The acquisitions from the original $\mathrm{La}$ mont selections were not vast, yet the survey was valuable in determining the strength of specific subject fields and in revealing a general showing of the holdings on an academic basis. The Air University Library is rich in specialized resources which extend beyond those of a general college library. These resources contribute vitally to the success of the library mission in support of the educational objectives of the United States Air Force. A continuous program is directed toward the refinement of these materials as to quality, timeliness and emphasis. There are certain required subject fields coincident with those of undergraduate libraries. This similarity is more evident in specific divisions of a subject rather than a broad area. The Air University Library will continue to develop these parallels and acquire therein the best available materials within the undergraduate scope. The printed Catalogue of the Lamont Library (Harvard University Press, 1953), revised and brought up to date, invites an extended examination toward the further expansion of the relevant fields of interest.

\section{LPRT Newsletter}

The October issue of the new quarterly LPRT Newsletter, published at Porter Library, Kansas State Teachers College, Pittsburg, Kansas, will soon be distributed. A subscription to this publication goes along with membership in the ALA Library Periodicals Round Table. Membership is open to all persons interested in library periodicals, whether they are directly connected with such a publication or not. A fee of \$I.oo, sent to W. P. Kellam, Director of Libraries, University of Georgia, Athens, Georgia, will make you a member and bring you the LPRT Newsletter.

Past issues of the LPRT Newsletter have included articles on "Circulation and Exchange Analysis of Library Periodicals," "Editorial Policies of Library Periodicals" and many other timely studies relating to the library periodical field. The forthcoming October issue will contain articles on "Standards for Professional Library Periodicals" by Leon Carnovsky, "A Comparison of British and American Library Periodicals" by John Nolan, "Care and Feeding of State Bulletins" by Karl Brown, to name a few.

C\&RL extends best wishes to the $L P R T$ Newsletter for its continuing success. 